\title{
Pengaruh Pelatihan Pemusatan Perhatian (Mindfulness) Terhadap Peningkatan Empati Perawat
}

\section{The Effect of Mindfulness Training to Enhance the Empathy Level of Healthcare Professionals}

\author{
Umniyah \\ Tina Afiatin* \\ Fakultas Psikologi UGM, Yogyakarta 55281 \\ Diterima 20 April 2009 / Disetujui 20 Mei 2009
}

\begin{abstract}
This research is aimed to recognize the effect of mindullness training to enhance the empathy level of healthcare professionals (nurse). The design of this research is randomized pretest-posttest control group design. The instrument of measurement in this research is Empathy Scale, observation, interview and sharing ideas. The result of the one way anova analysis indicated that there was a significant difference of empathy score in post-test measurement between experimental group and control group, which $F=$ 20,$724 ; p=0,001(p<0,05)$. It means that mindullness training was effective for enhancing the empathy level of healthcare professional (nurse).
\end{abstract}

Key words: empathy, mindfuiness, healthcare professionals (nurse).

Salah satu sumber daya manusia di rumah sakit yang sangat menentukan kualitas pelayanan kesehatan adalah tenaga keperawatan. Jumlah mereka sekitar 60 persen di rumah sakit (www.republika.co.id, 19/02/08). Tenaga keperawatan tersebut melayani pasien sesuai dengan keyakinan profesi dan standar yang ditetapkan agar pelayanan yang diberikan senantiasa aman serta dapat memenuhi kebutuhan dan harapan pasien (Nurachmah, 2008).

Mengingat besarnya peran perawat dalam proses penyembuhan pasien, maka perawat harus menumbuhkan dan mengembangkan sifat-sifat dan sikap-sikap yang dapat membantu pasien meringankan dan mengurangi penderitaannya (Gunarsa \& Gunarsa, 1989). Hal yang sama dinyatakan oleh Nurachmah (2008) bahwa dalam mewujudkan asuhan keperawatan bermutu diperlukan beberapa komponen yang harus dilaksanakan oleh tim keperawatan yaitu: (1) Terlihat sikap peduli (caring) kepada pasien; (2) Adanya hubungan terapeutik antara perawat klien; (3) Kolaborasi dengan anggota tim kesehatan lain; (4) Kemampuan memenuhi kebutuhan klien; (5) Kegiatan jaminan mutu (quality assurance).

\footnotetext{
*Penulis Korespondensi :

Telp. (0274) 550435, HP. 081227504, Email : afiatin04@ugm.ac.id
} 
Sifat lain yang penting dimiliki perawat adalah kemampuan untuk memberikan respon empatik. Empati sangat diperlukan dan harus dikuasai oleh petugas yang terlibat dalam pelayanan kesehatan karena merupakan kemampuan yang mendahului timbulnya perilaku prososial (Hemmerdinger, dkk., 2007; Beddoe \& Murphy, 2004; Planalp, 1999). Hoffman (Eisenberg, 2004) mengungkapkan bahwa perilaku prososial, khususnya altruisme, dimotivasi oleh empati yang dimiliki seseorang. Empati memiliki beberapa fungsi yang dapat membantu seseorang dalam bersosialisasi, berinteraksi, berkomunikasi dan bersikap di lingkungan masyarakat (Hojat, dkk., 2005). Batson, dkk., (Brehm \& Kassim, 1993) dan Staub (1978) mengungkapkan bahwa empati merupakan salah satu faktor yang mendorong seseorang menolong orang lain. Seseorang yang mampu berempati akan lebih mudah merasakan apa yang dirasakan dan apa yang dialami oleh orang lain, baik itu sesuatu yang menyenangkan atau tidak menyenangkan.

Stepien \& Baernstein (2006), Mercer \& Reynolds (2002), Brehm \& Kassim (1993) menyatakan bahwa empati dalam pelayanan keperawatan merupakan suatu konsep multidimensional yang kompleks yang terdiri dari: (1) Komponen kognitif, yaitu kemampuan intelektual untuk mengidentifikasi dan memahami perasaan orang lain. Komponen kognitif ini terdiri dari : (a) Alih peran (perspective taking), merupakan kecenderungan individu untuk mengambil alih secara spontan sudut pandang orang lain; (b) Fantasi (fantasy), yaitu kecenderungan seseorang untuk mengubah diri ke dalam perasaan dan tindakan dari karakter-karakter khayalan yang terdapat pada buku-buku, layar kaca, bioskop, maupun dalam permainan-permainan. (2) Komponen afektif, merupakan kemampuan untuk mengalami dan berbagi perasaan dengan orang lain. Komponen afektif terdiri dari (a) perhatian empatik (empathic concern), merupakan orientasi seseorang terhadap orang lain yang berupa perasaan simpati dan peduli terhadap orang lain yang ditimpa kemalangan (b) Distres diri (personal distress), merupakan orientasi seseorang terhadap dirinya sendiri dan meliputi perasaan cemas dan gelisah pada situasi interpersonal. Distres diri (personal distress) yang tinggi berhubungan dengan rendahnya tingkat kemampuan sosial.

Adanya berbagai keluhan masyarakat mengenai kualitas pelayanan keperawatan menunjukkan bahwa ternyata masih terdapat perawat yang kurang berempati terhadap pasiennya, meskipun telah dibekali dengan kurikulum pendidikan keperawatan yang sangat memadai. Faktor yang menyebabkan seorang perawat kehilangan rasa empati dalam merawat pasien antara lain seperti yang diungkapkan oleh Connelly (2005). la menyatakan bahwa kondisi pekerjaan yang penuh tekanan akan mengakibatkan berkurangnya perhatian seorang perawat kepada pasien, tidak menyadari kebutuhan pasien dan terperangkap pada 
interaksi perawat-pasien yang bersifat rutin.

Upaya untuk meningkatkan empati banyak dilakukan, namun pada umumnya penelitian lebih banyak menekankan pada dimensi kognitif dan perilaku dari empati (Halpern, 2007; Beddoe \& Murphy, 2004). Beddoe \& Murphy (2004) mengungkapkan bahwa empati tidak hanya terdiri dari dimensi kognitif dan perilaku saja, melainkan merupakan kemampuan yang juga melibatkan dimensi afeksi dan moral. Selanjutnya Beddoe \& Murphy (2004) menyatakan bahwa pelatihan empati yang menggunakan pendekatan perilaku dan belajar kemungkinan akan menunjukkan hasil yang kurang baik di masa yang akan datang jika tidak dilakukan perubahan pada metode pelatihan peningkatan empati. Oleh karena itu diperlukan perubahan dari pendekatan perilaku dan komunikasi kepada pendekatan yang menekankan pada dimensi moral, afeksi dan proses-proses intrapersonal. Pendapat ini didukung oleh Halpern (2007) yang menjelaskan bahwa kemampuan empati pada petugas kesehatan dapat ditingkatkan dengan latihan meditasi, berbagi (sharing), menuliskan pengalaman, membaca dan menonton film yang berhubungan dengan empati.

Salah satu bentuk meditasi adalah pemusatan perhatian. Davis, dkk. (2007) menyebutkan bahwa pemusatan perhatian merupakan suatu bentuk meditasi pikiran yang melibatkan pemusatan perhatian pada setiap peristiwa dari seluruh pengalaman hidup, tanpa mempedulikan apakah pengalaman tersebut hebat atau hanya biasa-biasa saja. Pelatihan pemusatan perhatian merupakan suatu metode meditasi yang dapat meningkatkan empati dan terdiri dari kombinasi dimensi afektif, kognitif, moral, intrapersonal dan interpersonal (Beddoe \& Murphy, 2004; Allen \&. Knight, 2005). Pandangan utama metode pemusatan perhatian adalah pikiran individu sendiri yang membentuk dunia dan hal ini memiliki kesamaan dengan pandangan teori kognitif perilaku (Allen \& Knight, 2005). Teori kognitif perilaku dan pemusatan perhatian berusaha membantu individu untuk memahami bagaimana pikiran muncul, konsekuensi pikiran terhadap perasaan dan perilaku serta bagaimana mengelola pikiraan dan hasrat tersebut (Allen \&. Knight, 2005). Pelatihan pemusatan perhatian sangat bermanfaat bagi pemberi pelayanan kesehatan untuk lebih memahami pasien dan memudahkan hubungan serta komunikasi dalam situasi medis yang serba kompleks dan sulit (Connely, 2005). Oleh karena itu, peneliti tertarik untuk menerapkan Pelatihan pemusatan perhatian sebagai pendekatan untuk meningkatkan empati pada perawat.

Segal, dkk. (Rohan, 2003) serta Davis, dkk. (2007) mengungkapkan bahwa pemusatan perhatian merupakan suatu bentuk strategi pengaturan diri yang melibatkan pemusatan perhatian, merespon pikiran, sensasi dan emosi dengan sikap penerimaan, tanpa 
penilaian serta kesadaran akan situasi dan peristiwa saat ini. Germer (2005) menyebutkan ada tiga komponen utama dalam pemusatan perhatian (mindfulness), yaitu kesadaran (awareness), pengalaman saat ini (present experience) dan penerimaan (acceptance). Proses pemusatan perhatian (mindfulness) memiliki kriteria yang harus dipenuhi, di antaranya: (a) Nonkonseptual, merupakan kesadaran tanpa proses pemikiran; (b) Fokus pada peristiwa sekarang; (c) Tanpa penilaian (non-judgemental); (d) Dilakukan dengan sengaja (intentional); (e) Observasi partisipan; (f) Nonverbal; (g) Membebaskan (liberating) (Germer, 2005). Suatu pengamatan yang dilakukan secara mindful dapat mendorong seseorang untuk berempati terhadap objek yang diamati. Mindful merupakan suatu tindakan yang dilakukan dengan kesadaran penuh dan dengan sikap menerima tanpa mengadili (Mathias, dkk., 2008).

Pemusatan perhatian (mindfulness) telah banyak digunakan dan terbukti efektivitasnya dalam mengatasi berbagai masalah psikologis. Sebagai contoh adalah Helen \& Teasdale (2004) yang meneliti efektivitas Terapi Kognitif Berbasis Pemusatan Perhatian atau Mindfulness-Based Cognitive Therapy (MBCT) dalam mencegah terjadinya kekambuhan pada 75 pasien depresi berulang yang sedang menjalani pengobatan anti depresan dan sedang mengalami proses remisi. Singh, dkk. (2007) meneliti efek Pelatihan Pemusatan Perhatian (Mindfulness Training) terhadap tiga orang remaja penderita gangguan perilaku (conduct disorder) dan hampir dikeluarkan dari sekolah. Hasil penelitiannya menunjukkan bahwa Pelatihan Pemusatan Perhatian (Mindfulness Training) dapat menurunkan perilaku agresif dan mengganggu pada remaja penderita gangguan perilaku. Pemusatan perhatian (mindfulness) juga dapat menurunkan kecemasan, seperti pada penelitian Davis, dkk. (2007). Hasil penelitian Davis, dkk. menunjukkan bahwa pemusatan perhatian dapat menurunkan kecemasan pada penderita skizofrenia.

Pemusatan perhatian (mindfulness) juga merupakan suatu pendekatan yang menggunakan berbagai metode yang dapat mengembangkan kapasitas empati individu (Block-lerner, dkk., 2007). Metode pemusatan perhatian (mindfulness) merupakan salah satu cara untuk menyadari perilaku, kebiasaan dan reaksi sendiri serta sangat bermanfaat bagi pemberi pelayanan kesehatan untuk lebih memahami pasien dan bermanfaat dalam memudahkan hubungan dan komunikasi dalam situasi medis yang serba kompleks dan sulit (Connely, 2005). Penelitian Shapiro, dkk. (1998); Beddoe \& Murphy (2004); Anna, dkk. (2006) menemukan bahwa Pelatihan Pemusatan Perhatian dapat meningkatkan kemampuan empati, memperbaiki manajemen hubungan antara perawat dan pasien serta mengurangi stres mahasiswa keperawatan dan petugas kesehatan. Kabat-Zinn \& Kornfield (Beddoe \& Murphy, 2004) menyebutkan bahwa aspek-aspek yang dilatihkan dalam pemusatan perhatian 
untuk meningkatkan empati meliputi refleksi diri, penerimaan terhadap diri dan orang lain, mengembangkan potensi untuk peduli terhadap orang lain serta terbuka terhadap masalah tanpa menghindar. Adapun teknik-teknik yang digunakan antara lain: pendeteksian tubuh (body scan), meditasi duduk (sitting meditation) yang meliputi observasi pernapasan, sensasi tubuh, emosi dan pikiran, hatha yoga dan meditasi berjalan (walking meditation) (Shapiro, dkk., 1998; Beddoe \& Murphy, 2004; Anna, dkk., 2006).

Pelatihan Pemusatan Perhatian (Mindfulness Training) yang selanjutnya akan dilaksanakan dalam penelitian ini disusun oleh peneliti dengan mengacu pada metode pemusatan perhatian (mindfulness) untuk mengurangi stres dan meningkatkan empati pada siswa perawat (Beddoe \& Murphy, 2004), pemusatan perhatian untuk mengatasi kecemasan pada pasien skizofrenia (Davis, dkk., 2007), dan Pelatihan Pemusatan Perhatian (Mindfulness Training) yang berdasarkan kognitif terhadap petugas kesehatan (Anna, dkk., 2006). Penelitian ini terdiri dari delapan sesi pelatihan dengan lima teknik yang terdiri dari: meditasi menyadari pernapasan (short breathing/breath meditation), pendeteksian tubuh dengan sikap penghargaan (compassionate body scan), latihan menyadari sensasi tubuh (body sensation), membuka kesadaran (open awareness), menerima pikiran dan perasaan, serta melepaskan hasrat (wanting release).

Hasil akhir yang diharapkan melalui Pelatihan Pemusatan Perhatian ini adalah perawat mampu mengembangkan kapasitas-kapasitas yang dibutuhkan untuk meningkatkan empati, sehingga pada akhirnya perawat mampu menjalin interaksi yang lebih terapiutik dengan pasien dan meningkatkan kualitas pelayanan keperawatan. Kerangka berpikir mengenai pengaruh Pelatihan Pemusatan Perhatian (Mindfulness Training) dalam meningkatkan kemampuan empati perawat dapat dilihat pada Gambar 1 berikut. 


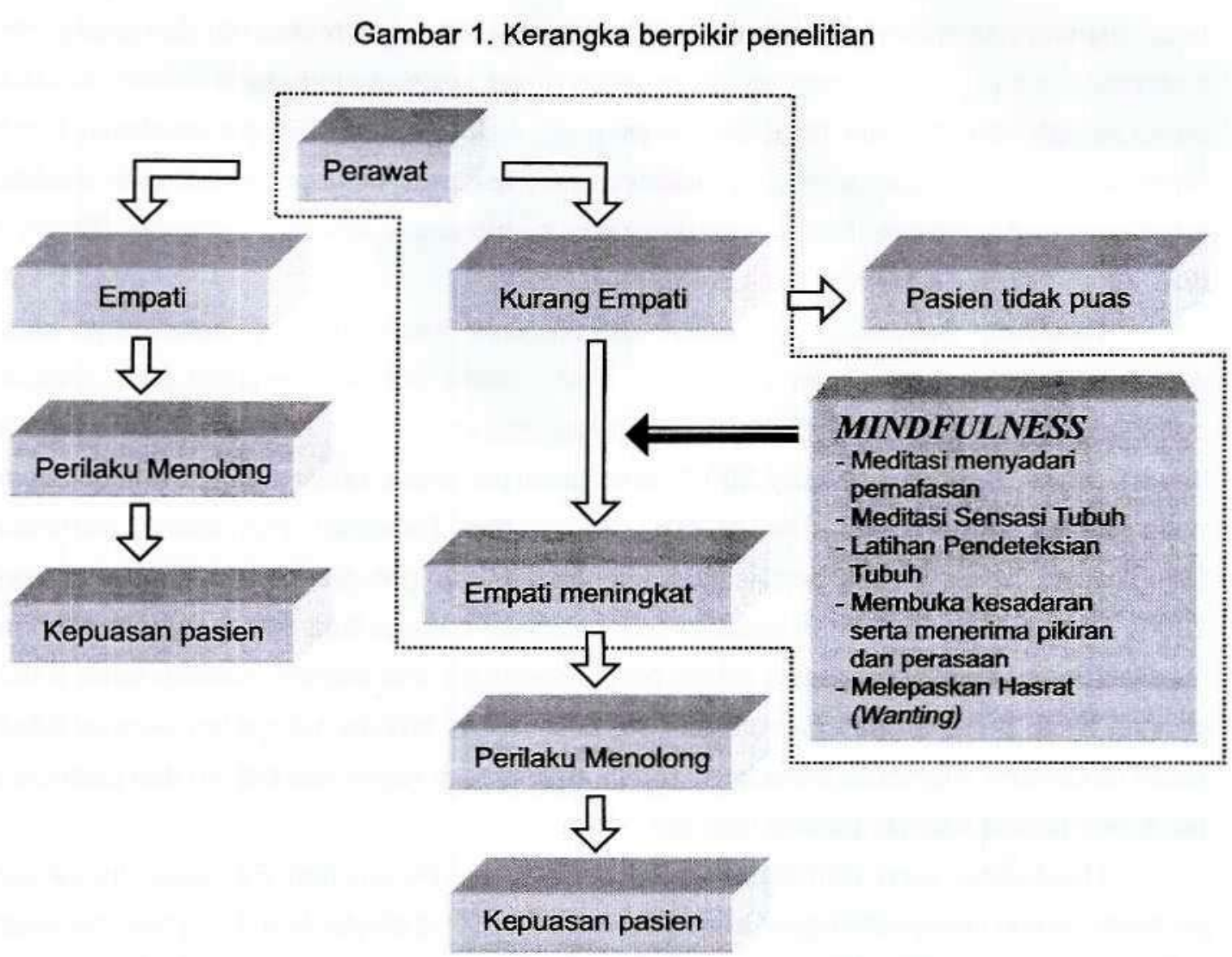

Keterangan:

$\sqrt{5}$ : Terdiridari

I) : Menyebabkan

$\Leftarrow \quad$ : Intervensi yang diberikan

: Area penelitian

Tujuan penelitian ini adalah untuk mengetahui pengaruh Pelatihan Pemusatan Perhatian (Mindfulness Training) terhadap peningkatan empati perawat. Hipotesis yang diajukan dalam penelitian ini adalah Pelatihan Pemusatan Perhatian (Mindfulness Training) dapat meningkatkan kemampuan empati perawat. 


\section{Metode Penelitian}

\section{Partisipan}

Partisipan dalam penelitian ini berjumlah 20 orang perawat di salah satu RSJ di Jawa Tengah, dengan kriteria: usia antara 20 - 40 tahun, masa kerja lebih dari satu tahun, tidak sedang mengikuti psikoterapi atau konseling lebih dari satu kali setiap bulan, serta tidak sedang mengikuti meditasi lebih dari satu kali per minggu atau mengikuti yoga lebih dari dua kali per minggu.

\section{Rancangan Penelitian}

Penelitian ini merupakan penelitian quasi experiment yang bertujuan untuk mengetahui pengaruh perlakuan yang berupa Pelatihan Pemusatan Perhatian terhadap peningkatan empati pada perawat. Desain penelitian yang digunakan adalah rancangan prates-pascates dengan kelompok kontrol secara random (randomized pretest-posttest control group design), yakni sebagai berikut:

Tabel 1. Rancangan Penelitian

\begin{tabular}{lcccc}
\hline Kelompok & Prates & Perlakuan & Pascates & Tindak Lanjut \\
\hline Eksperimen & Y1 & $\mathrm{X}$ & $\mathrm{Y} 2$ & $\mathrm{Y} 3$ \\
Kontrol & $\mathrm{Y} 1$ & - & $\mathrm{Y} 2$ & $\mathrm{Y} 3$ \\
\hline
\end{tabular}

\section{Keterangan:}

Y1: skor skala empati pada saat prates.

Y2: skor skala empati pada saat pascates.

Y3: skor skala empati pada saat tindak lanjut.

$\mathrm{X}$ : perlakuan berupa pelatihan pemusatan perhatian

\section{Pengumpulan Data}

Pengukuran secara kuantitatif. Berkaitan dengan pengukuran secara kuantitatif, peneliti melakukan langkah-langkah sebagai berikut:

1. Penyusunan Skala Empati dilakukan sendiri oleh peneliti. Skala Empati ini berisi beberapa kasus yang menggambarkan situasi-situasi yang biasa dialami oleh perawat. Pada masing-masing kasus diberikan pertanyaan mengenai apa yang dipikirkan, dirasakan dan yang akan terjadi pada tokoh yang terdapat dalam kasus.

2. Melakukan penilaian pakar (professional judgment) oleh dosen Fakultas Psikologi UGM 
dan perawat kesehatan jiwa. Hasilnya menunjukkan dari sembilan kasus yang terdapat pada skala, dua kasus dinyatakan tidak jelas atau ambigu. Dua kasus ini selanjutnya tidak dipakai untuk tahap selanjutnya.

3. Melakukan penilaian (rating) untuk menentukan skor pada masing-masing pilihan jawaban. Penilaian ini dilakukan oleh lima perawat puskesmas, tiga perawat RSU, dan 50 mahasiswa keperawatan.

4. Melakukan uji coba Skala Empati pada tanggal 21 Juli 2008. Uji coba diberikan kepada 50 mahasiswa keperawatan semester akhir yang telah melakukan praktek kerja lapangan. Hasil uji coba menunjukkan dua item dinyatakan gugur, sehingga total item menjadi 23 item. Koofisien korelasi item total bergerak antara 0,276 sampai 0,713 dan koefisien alpha sebesar 0,924 .

Skala Empati digunakan untuk mengukur tingkat empati partisipan sebelum, sesudah perlakuan dan tindak lanjut (follow-up).

Pengukuran secara kualitatif. Berbagi (sharing) dilakukan untuk memperoleh data kualitatif mengenai pengalaman yang dirasakan partisipan selama proses pelatihan, manfaat yang dirasakan setelah mengikuti pelatihan serta faktor-faktor yang mendukung dan menghambat proses penerapan latihan pemusatan perhatian dalam kehidupan sehari-hari maupun dalam pekerjaan. Wawancara dilakukan dengan rekan kerja partisipan untuk memperoleh data kualitatif mengenai perkembangan dan perubahan perilaku yang ditunjukkan oleh partisipan setelah mengikuti pelatihan. Observasi dilakukan untuk memperoleh data mengenai perilaku partisipan selama proses pelatihan berlangsung.

\section{Intervensi}

Intervensi yang dilakukan berupa Pelatihan Pemusatan Perhatian untuk meningkatkan empati pada perawat. Program pelatihan terdiri dari delapan sesi, dengan enam kali pertemuan dan setiap pertemuan berdurasi dua jam. Teknik-teknik yang digunakan dalam pemusatan perhatian terdiri dari: (1) Meditasi menyadari pernapasan; (2) Meditasi sensasi tubuh; (3) Latihan pendeteksian tubuh; (4) Membuka Kesadaran; (5) Menerima pikiran dan perasaan; (6) Membebaskan diri dari hasrat.

Persiapan intervensi. Ada beberapa langkah yang dilakukan dalam persiapan penelitian, di antaranya:

1. Melakukan studi pendahuluan untuk menindaklanjuti hasil kajian pustaka dan temuan di media masa dengan teknik wawancara.

2. Penyusunan modul Pelatihan Pemusatan Perhatian. Secara garis besar, modul Pelatihan 
Pemusatan Perhatian berisi tentang : pengertian pelatihan, tujuan pelatihan, waktu pelaksanaan pelatihan dan langkah-langkah pelaksanaan pelatihan yang terdiri dari delapan sesi. Sesi I berisi pembukaan, sesi II adalah menyadari pernapasan, sesi III berupa sensasi tubuh, sesi IV pendeteksian tubuh dengan sikap penghargaan, sesi $\mathrm{V}$ membuka kesadaran, sesi VI menerima pikiran dan perasaan, sesi VII melepaskan hasrat, serta sesi VIII berisi pemusatan perhatian dalam kehidupan sehari-hari.

3. Uji coba modul pelatihan. Uji coba dilakukan untuk mengetahui apakah prosedur pelatihan yang meliputi durasi waktu pada masing-masing sesi, kalimat instruksi, serta materi psikoedukasi, bisa dipahami oleh peserta. Uji coba modul dilakukan pada tanggal 24,25 dan 26 Juli 2008 dengan menggunakan teknik bermain peran (role play) dan diberikan kepada lima orang perawat puskesmas.

4. Melakukan seleksi fasilitator dan ko-fasilitator. Kualifikasi fasilitator dalam pelatihan pemusatan perhatian adalah: (a) Psikolog atau mahasiswa magister profesi yang telah melakukan praktek kerja profesi; (b) Memiliki pengalaman dalam relaksasi dan meditasi; (c) Telah mengikuti Pelatihan Pemusatan Perhatian untuk trainer; (d) Pernah menjadi fasilitator atau ko-fasilitator dalam pelatihan; (e) Memiliki kemampuan interpersonal yang baik dan memiliki beberapa kualifikasi keterampilan konselor seperti hangat, penuh penerimaan, dan empatik; (f) Memiliki pengetahuan mengenai empati pada perawat. Kualifikasi ko-fasilitator meliputi: (a) Mahasiswa magister profesi yang telah melakukan praktek kerja profesi; (b) Memiliki pengalaman dalam relaksasi dan meditasi; (c) Pernah menjadi fasilitator atau ko-fasilitator dalam pelatihan; (d) Memiliki kemampuan interpersonal yang baik dan memiliki beberapa kualifikasi keterampilan sebagai konselor seperti hangat, penuh penerimaan, dan empatik.

5. Melakukan pembekalan pelatihan pada fasilitator dan ko-fasilitator. Pembekalan ini dilakukan dengan tujuan agar fasilitator dan ko-fasilitator memahami materi pelatihan, prosedur pelaksanaan pelatihan, memudahkan dalam melakukan pelatihan, juga untuk menjelaskan hak dan kewajiban fasilitator. Pembekalan ini dilakukan dengan teknik bermain peran (role-play) pada semua sesi pelatihan.

6. Penentuan partisipan pelatihan. Penentuan partisipan ditentukan oleh Kepala Bidang Keperawatan dengan cara penunjukan. Penunjukan dilakukan atas dasar pertimbangan dan evaluasi Bidang Keperawatan terhadap kinerja beberapa perawat yang dipandang perlu untuk mengikuti Pelatihan Pemusatan Perhatian. Selanjutnya, 20 perawat yang telah ditunjuk diberikan Skala Empati untuk mengetahui tingkat empati yang dimiliki. Setelah itu dibagi ke dalam kelompok kontrol dan eksperimen secara acak melalui undian. 
Kelompok eksperimen diberikan Pelatihan Pemusatan Perhatian, sementara kelompok kontrol merupakan kelompok tunggu (waiting list) akan mendapatkan perlakuan setelah semua proses pelatihan selesai.

Pelaksanaan Penelitian. Pelatihan pemusatan perhatian dilakukan sebanyak delapan sesi dengan enam kali pertemuan. Tiap pertemuan berdurasi 2-2,5 jam. Jadwal pelaksanaan Pelatihan pemusatan perhatian dapat dilihat pada Tabel 1 berikut:

Tabel 1. Jadwal Pelaksanaan Pelatihan pemusatan perhatian

\begin{tabular}{|c|c|c|c|}
\hline Pertemuan & Sesi & Hari/tanggal & Kegiatan \\
\hline \multirow{2}{*}{1} & 1 & \multirow{2}{*}{ Sabtu/16-08-2008 } & $\begin{array}{l}\text { - Perkenalanan } \\
\text { - Pengantar Mindfulness }\end{array}$ \\
\hline & 2 & & Menyadari pernapasan (short breathing) \\
\hline II & 3 & Kamis/21-08-2008 & Sensasi Tubuh (body sensations) \\
\hline III & 4 & Sabtu/23-08-2008 & $\begin{array}{l}\text { Pendeteksian Tubuh dengan sikap } \\
\text { penghargaan (compassionate body scan) }\end{array}$ \\
\hline \multirow[b]{2}{*}{ IV } & 5 & \multirow[b]{2}{*}{ Senin/25-08-2008 } & Membuka Kesadaran (open awareness) \\
\hline & 6 & & $\begin{array}{l}\text { Menerima pikiran dan perasaan } \\
\text { (accepting thoughts and emotions) }\end{array}$ \\
\hline V & 7 & Kamis/28-08-2008 & $\begin{array}{l}\text { Membebaskan diri dari hasrat } \\
\text { (wanting release) }\end{array}$ \\
\hline VI & 8 & Sabtu/30-08-2008 & Mindfulness dalam kehidupan sehari-hari \\
\hline
\end{tabular}

Tahap tindak lanjut ( follow-up) dilakukan dua minggu setelah pelatihan, yaitu pada hari Sabtu 13 September 2008. Tindak lanjut (follow up) dilakukan dengan memberikan Skala Empati dan juga melalui berbagi (sharing) untuk melihat sejauh mana pengaruh pelatihan pada partisipan dan penerapannya dalam kehidupan sehari-hari dan pekerjaan. Tahap terakhir yaitu tindak lanjut (follow-up) yang dilakukan pada tanggal 6 Oktober 2008. Pada tahap ini dilakukan wawancara pada rekan kerja partisipan untuk memperoleh informasi kemajuan serta kinerja partisipan setelah mengikuti Pelatihan Pemusatan Perhatian.

\section{Metode Analisis Data}

Analisis data kuantitatif untuk menguji hipotesis dilakukan dengan menggunakan analisis statistik dengan teknik analisis varian (Anava) satu jalur. Analisis data kualtatif dilakukan terhadap data yang diperoleh dari hasil observasi selama pelatihan, hasil berbagi (sharing) dan wawancara. 


\section{Hasil Penelitian}

Hasil penelitian ini dibagi menjadi dua bagian, yaitu hasil analisis kuantitatif dan hasil analisis kualitatif.

\section{Hasil Analisis Kuantitatif}

Data yang diperoleh dalam penelitian ini adalah skor empati partisipan antara kelompok eksperimen dan kelompok kontrol berdasarkan Skala Empati yang diberikan sebelum (pre-test), setelah (post-test) pelatihan dan follow-up. Statistik deskriptif penelitian dapat dilihat pada tabel 2 berikut:

Tabel 2. Statistik Deskriptif

\begin{tabular}{lcccccc}
\hline \multirow{2}{*}{ Kelompok } & \multicolumn{5}{c}{ Statistik deskriptif } \\
\cline { 2 - 7 } & \multicolumn{2}{c}{ Prates } & \multicolumn{2}{c}{ Pasctes } & \multicolumn{2}{c}{ Tindak lanjut } \\
\cline { 2 - 7 } & $\bar{X}$ & SD & $\bar{X}$ & SD & $\bar{X}$ & SD \\
\hline Eksperimen & 54,0 & 3,127 & 60,4 & 4,088 & 60,5 & 3,951 \\
Kontrol & 53,1 & 3,381 & 53,4 & 2,633 & 53,3 & 2,540 \\
\hline
\end{tabular}

Pengujian hipotesis dilakukan dengan uji statistik yaitu Analisis Varian (Anava) satu jalur untuk melihat pengaruh Pelatihan Pemusatan Perhatian terhadap peningkatan empati perawat. Hasil analisis data dengan Anava dapat dilihat pada Tabel 3 berikut:

Tabel 3. Rangkuman Anava Skor Empati Kelompok Kontrol dan Eksperimen

\begin{tabular}{|c|c|c|c|c|c|c|}
\hline Sumber Variasi & $\begin{array}{l}\text { Variabel } \\
\text { Dependen }\end{array}$ & JK & $\mathrm{db}$ & RK & $F$ & $p$ \\
\hline $\begin{array}{c}\text { Antar Kelompok } \\
\text { Eksperimen-kontrol }\end{array}$ & $\begin{array}{c}\text { Pascates } \\
\text { Tindak lanjut }\end{array}$ & $\begin{array}{l}245,000 \\
259,200\end{array}$ & $\begin{array}{l}1 \\
1\end{array}$ & $\begin{array}{l}245,000 \\
259,200\end{array}$ & $\begin{array}{l}20,724 \\
23,492\end{array}$ & $\begin{array}{l}0,001 \\
0,001\end{array}$ \\
\hline
\end{tabular}

Tabel 3 tersebut menunjukkan bahwa ada perbedaan skor empati yang signifikan antara kelompok eksperimen dan kelompok kontrol pada pengukuran sesudah perlakuan (post-test) dengan $F=20,724$ dan $p=0,001(p<0,05)$. Pada follow-up terdapat perbedaan yang signifikan antara kelompok kontrol dan kelompok eksperimen dengan $F=23,492$ dan $p=$ 0,001 ( $p<0,05$ ). Selanjutnya perbedaan rata-rata skor empati kelompok eksperimen dan kelompok kontrol pada masing-masing pengukuran dapat dilihat pada Gambar 2 berikut: 
Gambar 2. Grafik Rata-rata Skor Empati pada Masing-masing Pengukuran

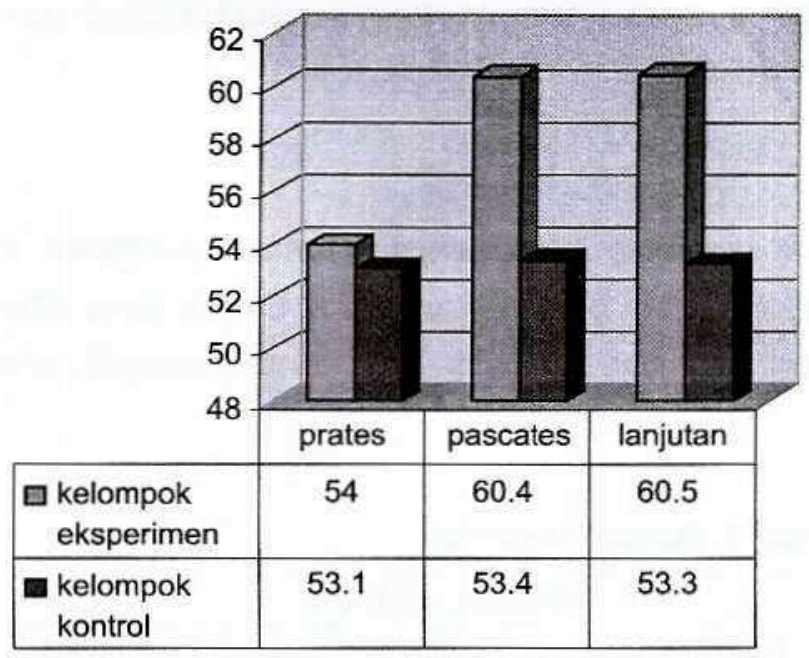

$\square$ kelompok eksperimen

kelompok kontrol

Berdasar Gambar 2 dapat disimpulkan bahwa rata-rata skor empati kelompok kontrol lebih rendah dibanding kelompok eksperimen sesudah perlakuan. Selanjutnya untuk melihat perbedaan skor empati pada kelompok eksperimen sebelum dan sesudah perlakukan dilakukan analisis dengan anava satu jalur. Hasil analisis tersebut dapat dilihat pada Tabel 4 berikut:

Tabel 4. Rangkuman Hasil Anava Skor Empati pada Kelompok Eksperimen

\begin{tabular}{crrrrr}
\hline Sumber Variasi & JK & db & RK & \multicolumn{1}{c}{ F } & p \\
\hline Prates - pascates & 204,800 & 1 & 204,800 & 15,463 & 0,001 \\
Pascates - tindak lanjut & 0,050 & 1 & 0,050 & 0,003 & 0,956 \\
\hline
\end{tabular}

Berdasar Tabel 4 dapat diketahui bahwa terdapat perbedaan yang signifikan antara skor empati sebelum dan sesudah perlakuan dengan $F=15,463$ dan $p=0,001(p<0,05)$. Selanjutnya dari Tabel 4 juga dapat dilihat tidak terdapat perbedaan yang signifikan skor empati segera sesudah perlakuan (post-test) dan pada saat follow-up dengan $F=0,003$ dan $p$ $=0,956(p>0,05)$, artinya pengaruh Pelatihan Pemusatan Perhatian terhadap skor empati perawat tetap bertahan dalam kurun waktu dua minggu setelah pelatihan.

Berdasarkan hasil analisis kuantitatif di atas, maka dapat disimpulkan bahwa hipotesis yang diajukan dalam penelitian ini dapat diterima, yaitu Pelatihan Pemusatan Perhatian dapat meningkatkan kemampuan empati perawat. 


\section{HasilAnalisis Kualitatif}

Analisis kualitatif dilakukan pada kelompok eksperimen berdasarkan: (1) Skor pada Skala Empati dan hasil berbagi (sharing) pada masing-masing sesi; (2) Berbagi (sharing) pengalaman melakukan latihan meditasi di rumah (berdasarkan buku harian); (3) Hasil observasi selama proses pelatihan; (4) Berbagi (sharing) pada tahap tindak lanjut (follow-up) serta; (5) Hasil wawancara dengan rekan kerja pada tahap tindak lanjut (follow-up). Tujuan analisis kualitatif adalah untuk mengetahui pengalaman peserta dalam mengikuti masingmasing sesi pelatihan dan pengalaman emosional yang dirasakan selama dan setelah melakukan latihan masing-masing teknik meditasi. Analisis ini dilakukan terhadap peserta yang mengalami peningkatan skor Skala Empati yang tinggi dan terhadap peserta yang mengalami peningkatan skor Skala Empati rendah.

Peserta yang mengalami peningkatan skor empati yang tinggi. Salah satunya adalah peserta nomor 5 (Brr). Secara umum Brr tampak aktif dan antusias mengikuti pelatihan. Brr aktif mengemukakan pendapat atau mengajukan pertanyaan seputar materi yang disampaikan. Selain itu Brr juga selalu melakukan latihan meditasi pada masing-masing teknik di rumah paling tidak satu kali di antara rentang waktu pelaksanaan masing-masing sesi. Skor Skala Empati Brr sebelum pelatihan adalah 53 dan setelah pelatihan 63. Artinya Brr mengalami peningkatan skor dari kategori sedang menjadi kategori tinggi. Pada tindak lanjut (follow up) yang dilakukan dua minggu setelah pelatihan, Skor Empati Brr tetap 63, artinya peningkatan skor empati tetap bertahan dua minggu pasca pelatihan. Grafik pada Gambar 3 menunjukkan peningkatan skor Skala Empati sebelum dan sesudah pelatihan dan tindak lanjut (follow-up).

Gambar 3. Skor Empati Sebelum dan Sesudah Perlakuan serta pada follow-up Subjek Brr

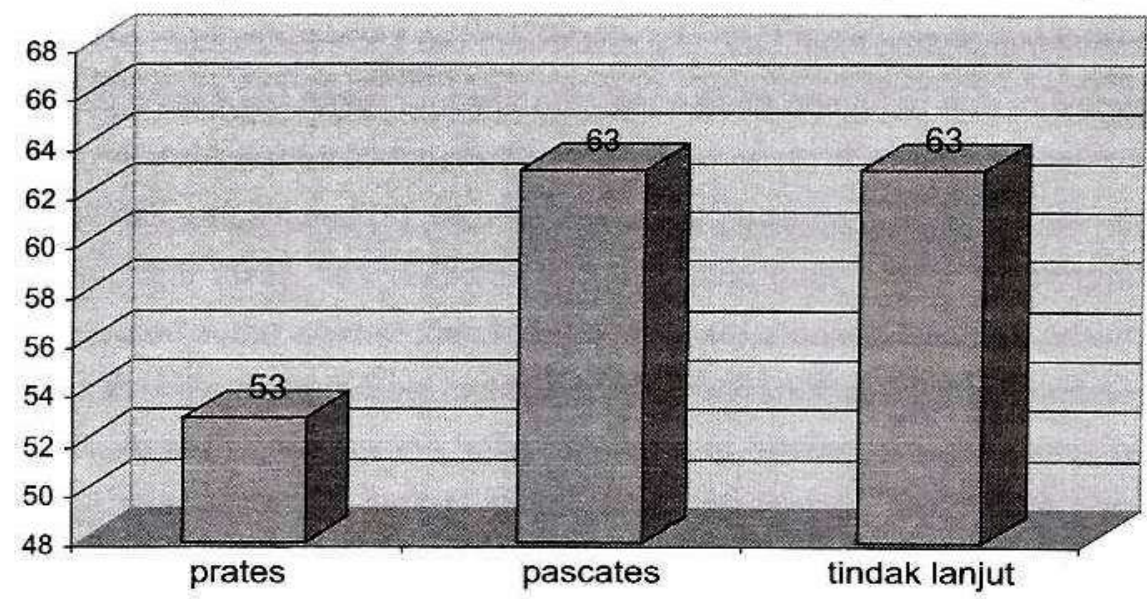


Pengalaman pelatihan pemusatan perhatian yang dialami Brr pada masing-masing teknik adalah sebagai berikut:

1. Meditasi menyadari pernafasan. Brr sangat antusias dan berusaha menjalankan latihan meditasi dengan sungguh-sungguh. Setelah melakukan latihan meditasi pada saat sesi pelatihan Brr mengungkapkan bahwa tubuhnya terasa nyaman dan tenang.

2. Meditasi sensasi tubuh. Pengalaman yang dirasakan setelah melakukan latihan meditasi sensasi tubuh adalah merasa tubuhnya menjadi lebih hangat, lebih rileks dan lebih nyaman.

3. Meditasi pendeteksian tubuh dengan sikap penghargaan. Setelah melakukan latihan meditasi pendeteksian tubuh, Brr merasa lebih bersyukur dan lebih bisa menghargai tubuh. Selain itu, Brr juga lebih tenang dalam menjalankan pekerjaan.

4. Meditasi membuka kesadaran, menerima pikiran, dan perasaan. Setelah melakukan latihan meditasi ini, Brr lebih dapat menerima perasaan yang tidak menyenangkan serta melepaskannya sehingga menjadi lebih lega dan berdamai dengan perasaan tersebut.

5. Meditasi melepaskan hasrat. Setelah melaksanakan latihan meditasi melepaskan hasrat, Brr merasa lebih bisa menikmati pekerjaan dan hidup tanpa harus terbebani oleh berbagai macam tuntutan.

6. Pemusatan perhatian dalam kehidupan sehari-hari. Setelah mengikuti semua sesi pelatihan dan mempraktekkan keterampilan pemusatan perhatian dalam kehidupan sehari-sehari, Brr bisa lebih rileks, lebih nyaman, lebih menghargai diri sendiri, lebih bisa menerima semua kondisi baik yang terjadi pada diri maupun pada orang lain, dan lebih bisa menjalankan pekerjaan dengan lebih tenang tanpa beban

Pada proses tindak lanjut (follow-up) dengan melakukan wawancara pada rekan kerja partisipan, diperoleh informasi bahwa setelah mengikuti Pelatihan Pemusatan Perhatian, Brr menunjukkan kinerja yang lebih baik. Hal tersebut ditunjukkan Brr dengan perilaku: (1) Lebih sering tersenyum dan menyapa pasien maupun sesama rekan kerja serta tidak membedabedakan pasien yang dirawat; (2) Lebih cepat tanggap apabila ada pasien yang membutuhkan pertolongan serta tidak ikut panik dalam situasi darurat; (3) Lebih sabar dan tidak mengeluh ketika menghadapi pasien yang sulit diatur; (4) Meluangkan waktu untuk mendengarkan keluhan pasien dan juga sesama rekan kerja; (5) Lebih terbuka untuk berbagi pengalaman dan pengetahuan dengan sesama rekan kerja; (6) Menyelesaikan pekerjaan tepat waktu.

Peserta yang mengalami peningkatan skor empati yang rendah. Salah seorang peserta yang mengalami peningkatan skor empati rendah adalah peserta nomor 1 (Adp). Skor Skala Empati Adp pada saat prates adalah 54 dan pada saat pascates adalah 56 . Artinya 
meskipun Adp mengalami kenaikan skor sebanyak dua poin, tetapi tetap berada dalam kategori sedang. Demikian juga ketika tindak lanjut (follow-up) yang dilakukan dua minggu setelah pelatihan, skor empati Adp tetap berada dalam kategori sedang dengan skor 56 , sebagaimana terlihat pada Gambar 4 berikut:

Gambar 4. Skor Empati Sebelum, Sesudah Perlakuan, dan Follow-up Subjek Adp

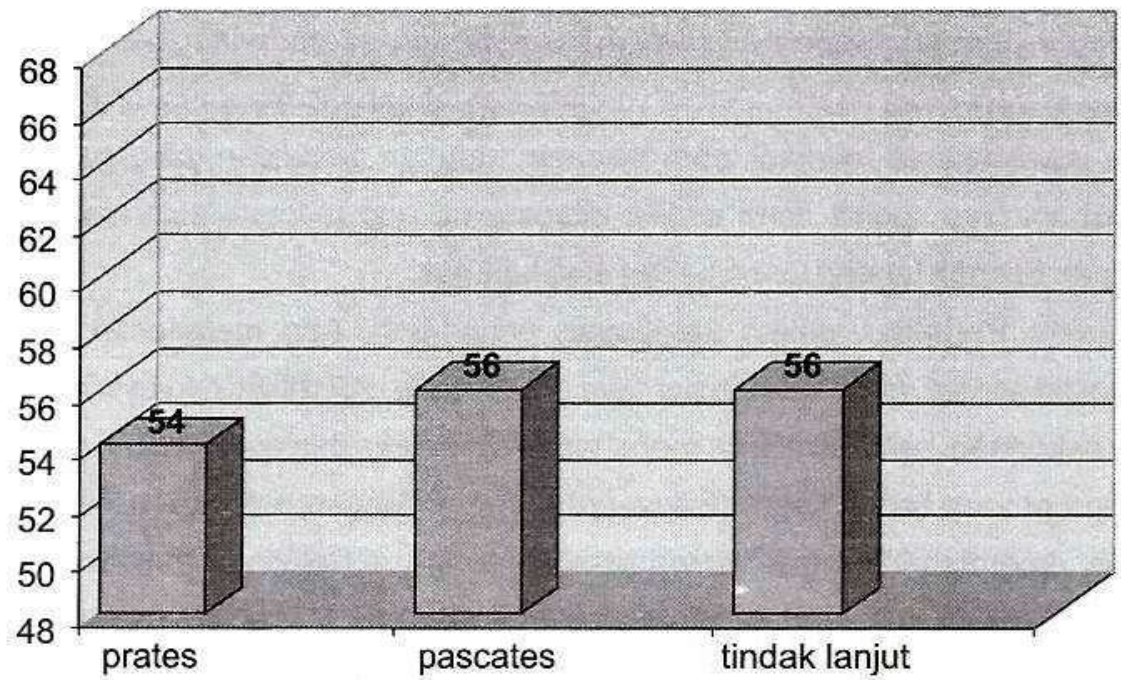

Selama mengikuti pelatihan Adp terlihat cukup aktif dan antusias. Selain itu Adp juga cukup kooperatif dan terbuka dalam mengungkapkan perasaannya. Sebagai perawat, Adp selalu bekerja pada jam kerja (shift) pagi sehingga ketika mengikuti pelatihan Adp terlihat cukup lelah setelah bekerja semenjak pagi. Akibatnya ketika melakukan latihan meditasi di kelas, Adp sulit untuk berkonsentrasi dan sering tertidur. Pengalaman dan perasaan yang dialamiAdp selama proses Pelatihan Pemusatan Perhatian, digambarkan sebagai berikut:

1. Meditasi menyadari pernafasan. Ketika melakukan latihan meditasi menyadari pernapasan, Adp terlihat mengikuti instruksi dengan seksama. Setelah selesai melakukan latihan pertama, Adp menceritakan pengalamannya yang masih belum bisa konsentrasi atau memusatkan perhatian. Pikirannya masih seringkali berpindah dari satu hal ke hal yang lain.

2. Meditasi sensasi tubuh. Setelah melakukan meditasi sensasi tubuh, Adp merasa cukup nyaman meskipun belum bisa konsentrasi untuk merasakan indra-indra. Ketika melakukan latihan di rumah, kendala yang paling dirasakan Adp adalah sulit konsentrasi dan sering kali melakukan latihan sampai tertidur.

3. Meditasi pendeteksian tubuh dengan sikap penghargaan. Setelah melakukan latihan 
meditasi pendeteksian tubuh dengan sikap penghargaan, Adp merasa terharu karena sering mengabaikan tubuh dan tidak pernah mengucapkan terima kasih pada tubuh. Selain itu, Adp juga merasakan pentingnya menghargai tubuh apapun keadaannya.

4. Meditasi membuka kesadaran, menerima pikiran dan perasaan. Setelah melakukan latihan meditasi ini, Adp merasa lebih tenang dan nyaman karena dapat melepaskan perasaan-perasaan yang tidak menyenangkan. Adp juga merasakan tubuhnya menjadi lebih ringan dan rileks seperti ada beban berat yang lepas atau hilang dari pundak.

5. Meditasi melepaskan hasrat. Setelah melakukan latihan meditasi ini, Adp mengemukakan bahwa perasaannya menjadi lebih nyaman, tuntutan pekerjaan yang selama ini selalu membebani bisa sedikit demi sedikit dilepaskan. Adp merasa lebih bisa menjalankan pekerjaan dengan tenang tanpa beban atau tuntutan.

6. Pemusatan Perhatian dalam kehidupan sehari-hari. Adp merasakan lebih nyaman dengan diri sendiri, merasa lebih percaya diri, merasa lebih rileks dan nyaman, lebih sabar dalam pekerjaan, serta lebih bisa menghargai diri sendiri dan orang lain.

Pada proses tindak lanjut (follow-up) lanjutan dengan melakukan wawancara pada rekan kerja, diperoleh informasi bahwa setelah mengikuti Pelatihan Pemusatan Perhatian, ada beberapa perubahan yang ditunjukkan oleh Adp, yaitu: (1) Lebih cepat tanggap apabila ada pasien yang membutuhkan pertolongan; (2) Lebih perhatian pada orang-orang di sekitar, menanyakan kabar dan menyapa pasien serta juga rekan-rekan kerja; (3) Lebih fokus pada pekerjaan dan berusaha menyelesaikan pekerjaan tepat waktu.

Berdasarkan pengalaman latihan meditasi peserta pelatihan yang mengalami peningkatan skor empati tinggi, peneliti menyimpulkan beberapa hal yang mendukung terjadinya peningkatan empati pada kedua peserta ini. Brr dan Nrh mengalami peningkatan skor empati yang tinggi karena memiliki motivasi yang tinggi untuk mengikuti semua proses pelatihan, terbuka untuk menceritakan pengalaman dan perasaannya serta berusaha menerima pengalaman dan perasaan tersebut, bersikap kooperatif, berusaha melaksanakan tugas yang diberikan, serta menerapkan keterampilan pemusatan perhatian dalam kehidupan sehari-hari. Sementara itu peserta yang mengalami peningkatan skor empati rendah, disebabkan kurang bisa konsentrasi selama dalam mengikuti proses latihan meditasi, kurang melakukan latihan meditasi di rumah, serta kurang terbuka terhadap perasaan yang dialami. 


\section{Pembahasan}

Hasil penelitian menunjukkan bahwa terdapat perbedaan yang signifikan skor empati partisipan pada kelompok eksperimen sebelum dan sesudah pelatihan. Sementara pada kelompok kontrol tidak terdapat perbedaan skor empati pada saat prates dan pascates. Berdasarkan hal itu dapat disimpulkan bahwa Pelatihan Pemusatan Perhatian efektif meningkatkan empati perawat. Hasil ini juga didukung oleh data kualitatif yang menunjukkan bahwa secara umum partisipan dalam pelatihan ini melaporkan adanya perubahan yang dirasakan setelah mengikuti pelatihan seperti merasa lebih nyaman, tenang, lebih menghargai diri dan orang lain serta merasa lebih sabar dalam menjalani pekerjaan.

Keberhasilan pelatihan yang telah dicapai dalam penelitian ini mendukung beberapa penelitian tentang efektivitas Pelatihan Pemusatan Perhatian dalam meningkatkan empati perawat. Penelitian tersebut antara lain yang dilakukan oleh Shapiro, dkk. (1998); Beddoe \& Murphy (2004); Anna, dkk. (2006), yang menemukan bahwa Pelatihan Pemusatan Perhatian dapat meningkatkan kemampuan empati, memperbaiki manajemen hubungan antara perawat dan pasien serta mengurangi stres petugas kesehatan.

Grieshaber (1994) mengemukakan bahwa terdapat beberapa faktor yang mempengaruhi keberhasilan suatu pelatihan, yaitu: modul, trainer, partisipan, dan fasilitas. Dalam hal ini, keberhasilan Pelatihan Pemusatan Perhatian dalam meningkatkan empati perawat turut dipengaruhi oleh modul pelatihan, trainer, dan karakteristik partisipan.

Modul pelatihan dalam penelitian ini disusun oleh peneliti berdasarkan aspek-aspek pemusatan perhatian untuk meningkatkan empati yang dikemukakan oleh Kabat-Zinn dan Kornfield (Beddoe \& Murphy, 2004). Aspek tersebut meliputi refleksi diri, penerimaan terhadap diri dan orang lain, mengembangkan potensi untuk peduli terhadap orang lain serta terbuka terhadap masalah tanpa menghindar. Modul ini kemudian dijabarkan dalam bentuk lima teknik pelatihan pemusatan perhatian, yaitu: meditasi menyadari pernapasan (short breathing/breath meditation), pendeteksian tubuh dengan sikap penghargaan (compassionate body scan), latihan menyadari sensasi tubuh (body sensation), membuka kesadaran (open awareness) dan menerima pikiran, perasaan, serta melepaskan hasrat (wanting release). Kelima teknik tersebut di atas, apabila diintegrasikan dan dilatihkan, akan mendukung terjadinya peningkatan empati pada perawat.

Teknik pertama, yaitu meditasi menyadari pernapasan. Berguna untuk membantu perawat untuk meningkatkan kemampuan konsentrasi, mencegah terjadinya proses kesalahan berpikir dan bertindak, serta melatih kemampuan menyadari dan mengantisipasi akibat serta manfaat setiap tindakan, baik untuk diri sendiri maupun orang lain. Setelah 
melakukan meditasi ini, partisipan mengungkapkan perubahan yang dirasakan seperti menjadi lebih tenang, dapat lebih konsentrasi dalam bekerja, tidak terburu-buru dalam bertindak, serta lebih sabar dalam menjalani pekerjaan.

Teknik ke dua, yaitu meditasi sensasi tubuh. Berfungsi untuk melatih kepekaan perawat dalam menghadapi situasi atau emosi yang ditunjukkan oleh pasien, serta meningkatkan kemampuan untuk memberikan respon yang tepat kepada pasien. Setelah melakukan meditasi ini, pada umumnya partisipan mengungkapkan pengalaman yang dirasakan seperti menjadi lebih peka untuk menggunakan indera dalam menghadapi setiap situasi.

Teknik ke tiga, yaitu latihan pendeteksian tubuh dengan sikap penghargaan. Teknik ini bertujuan untuk melatih perawat menumbuhkan penghargaan terhadap diri sendiri dan orang lain. Setelah melakukan latihan meditasi ini, pada umumnya partisipan mengungkapkan perubahan yang dirasakan seperti menjadi lebih menghargai dan mencintai tubuh serta lebih menghargai diri dan orang lain apa adanya.

Teknik ke empat, yaitu latihan membuka kesadaran, menerima pikiran, dan perasaan. Latihan ini bertujuan untuk membantu perawat agar lebih terbuka kepada setiap situasi atau peristiwa, baik yang bersifat menyenangkan maupun yang tidak, serta membantu untuk mengembangkan penerimaan tanpa melakukan penilaian. Setelah melakukan latihan ini, partisipan melaporkan adanya perubahan yang dialami seperti lebih bisa menerima berbagai peristiwa yang dialami sebagai bagian dari hidup, serta menjadi lebih mampu melepaskan perasaan-perasaan yang tidak menyenangkan yang selama ini dipendam.

Teknik ke lima, yaitu latihan meditasi melepaskan hasrat (wanting). Teknik ini membantu perawat untuk melepaskan hasrat yang mengganggu sehingga menumbuhkan sikap menerima, cinta, dan ikhlas baik terhadap diri sendiri maupun orang lain. Setelah melakukan latihan meditasi ini, partisipan mengungkapkan perasaannya yang lebih lega dan nyaman menjalankan pekerjaan tanpa dibelenggu oleh hasrat dan tuntutan.

Pada tindak lanjut (follow-up) yang dilakukan dua minggu setelah pelatihan berakhir, skor empati peserta tetap bertahan seperti pada pengkuran segera setelah pelatihan. Hal ini karena peserta tetap mempraktekkan keterampilan pemusatan perhatian dalam kehidupan sehari-hari. Seperti yang diungkapkan oleh partisipan bahwa dengan melakukan pemusatan perhatian dalam kehidupan sehari-hari terutama ketika menghadapi situasi dan kondisi yang tidak menyenangkan dirasakan manfaat berupa lebih rileks dan tenang dalam menjalankan pekerjaan, tidak terburu-buru, serta dapat berpikir lebih positif ketika menghadapi masalah. Allen dan Knight (2005) menyatakan bahwa latihan pemusatan perhatian individu akan 
menyadari dengan sepenuhnya peristiwa yang terjadi sekarang. Lebih lanjut Allen dan Knight (2005) menyatakan bahwa dengan mengelola suasana hati (mood) dan berpikir lebih positif individu lebih menyadari dan mendapatkan pemahaman tentang fungsi dan perannya dalam lingkungan sosial. Dalam hal ini adalah peran partisipan sebagai perawat dalam lingkungan rumah sakit.

Selain faktor teknik pemusatan perhatian yang digunakan, faktor lain yang juga mendukung keberhasilan pelatihan, yaitu partisipan yang terlibat dalam pelatihan. Hasil analisis kualitatif menunjukkan bahwa partisipan yang mengalami peningkatan skor empati yang tinggi didukung oleh beberapa hal, yaitu: adanya motivasi yang tinggi untuk mengikuti semua proses pelatihan, sikap terbuka untuk menceritakan pengalaman dan perasaannya, berusaha menerima pengalaman dan perasaan tersebut, bersikap kooperatif, berusaha melaksanakan tugas yang diberikan, serta menerapkan keterampilan pemusatan perhatian dalam kehidupan sehari-hari. Hal ini sesuai dengan komponen utama yang harus dipenuhi dalam proses pemusatan perhatian, yaitu: kesadaran (awareness), pengalaman saat ini atau fokus pada peristiwa sekarang, serta penerimaan (Germer, 2005). Selain itu motivasi partisipan ini tetap terjaga meskipun proses pelatihan telah berakhir. Partisipan tetap melakukan praktek meditasi dalam kehidupan sehari-hari sehingga pada pengukuran tindak lanjut (follow-up), skor empati partisipan cenderung tetap. Pada sisi lain, partisipan yang mengalami peningkatan skor empati yang rendah disebabkan kurang terpenuhinya komponen utama dalam proses pemusatan perhatian (kesadaran, fokus pada peristiwa sekarang dan penerimaan). Partisipan dalam kelompok ini meskipun menunjukkan sikap antusias dan berusaha mengikuti pelatihan dengan baik, namun masih kesulitan untuk fokus pada peristiwa saat ini, serta belum cukup terbuka untuk menerima dan melepaskan perasaan yang dimiliki.

Pelatihan pemusatan perhatian untuk meningkatkan empati perawat yang dilakukan dalam penelitian ini menggunakan pendekatan kelompok. Yalom (1985) mengungkapkan pendekatan kelompok memiliki banyak kelebihan yang disebut dengan faktor terapeutik, antara lain partisipan akan menemukan sesuatu tentang dirinya, menerima dukungan dan pemberian keyakinan dari anggota kelompok lain. Kelompok juga dapat digunakan untuk berbagi masalah dengan orang lain serta untuk mengembangkan keterampilan sosial (empati), mengenal dan mengubah perilaku anggota kelompok.

Faktor lain yang juga mendukung keberhasilan pelatihan, yaitu peran fasilitator. Pengalaman, penguasaan materi, serta kualitas interpersonal yang baik merupakan modal utama yang mendukung fasilitator dalam menjalankan tugas dengan baik. Dalam pelatihan ini 
fasilitator mampu memimpin proses pelatihan dengan baik, mampu menumbuhkan suasana keterbukaan dan keakraban di antara partisipan, mampu menjelaskan materi, serta memandu latihan meditasi dengan baik. Selain itu beberapa kemudahan yang mendukung pelaksanaan pelatihan ini juga terpenuhi, seperti ruangan yang kondusif (tenang, dingin, dan luas), ketersediaan perlengkapan audio visual (laptop, $L C D$, speaker) serta dukungan penuh dari instansi terkait.

Pelatihan pemusatan perhatian merupakan salah satu cara untuk meningkatkan empati perawat karena selama mengikuti pelatihan, peserta diajak untuk mengalami kembali di sini dan saat ini semua pengalaman emosional. Strayer dan Eisenberg (1990) mengungkapkan bahwa pengalaman sosial-emosional yang pernah dialami seseorang mempengaruhi kemampuan memahami berbagai macam emosi, pengalaman dan orang lain. Pengalaman sosial-emosional yang dialami membuat individu mempunyai rentang kemampuan emosional yang luas untuk memahami emosi yang dirasakan oleh diri sendiri dan orang lain sehingga dapat memperluas cakupan dan intensitas empati. Berdasarkan hasil penelitian juga diketahui bahwa pengukuran pada kelompok eksperimen saat pascates dan tindak lanjut menunjukkan hasil yang sama. Hal ini menunjukkan bahwa peningkatan empati perawat dapat bertahan dalam waktu yang cukup lama sesudah mengikuti Pelatihan Pemusatan Perhatian.

Beberapa kendala yang menjadi keterbatasan penelitian ini adalah sulitnya mengatur waktu pelaksanaan pelatihan karena harus menyesuaikan jadwal pelatihan dengan jadwal pelatih (trainer) serta jadwal jam kerja (shift) perawat yang menjadi partisipan. Akibatnya, rentang waktu antara pertemuan satu dengan pertemuan berikutnya menjadi bervariasi antara satu hingga tiga hari, sehingga pelaksanaan latihan di rumah menjadi kurang teratur karena menyesuaikan dengan pelaksanaan waktu pelatihan yang bervariasi. Selain itu, singkatnya jarak waktu antara masing-masing sesi kurang memberi kesempatan kepada partisipan untuk merasakan manfaat masing-masing teknik pemusatan perhatian. Keterbatasan lainnya adalah tidak dilakukannya evaluasi pelaksanaan meditasi di rumah (home visit), akibatnya aplikasi teknik meditasi secara mandiri tidak dapat dievaluasi secara tepat. Pada lembar persetujuan partisipan (informed consent) tidak dijelaskan secara rinci mengenai efek samping atau resiko ketidaknyamanan yang dapat dihadapi oleh partisipan, juga tidak dijelaskan apa yang akan dilakukan oleh peneliti apabila hal itu terjadi. 


\section{Simpulan dan Rekomendasi}

\section{Simpulan}

Hasil penelitian menunjukkan bahwa Pelatihan Pemusatan Perhatian dapat meningkatkan empati perawat. Peningkatan empati dapat tetap bertahan meskipun pelatihan telah selesai dilaksanakan. Selain meningkatkan skor empati, latihan pemusatan perhatian juga dapat memberikan rasa tenang, nyaman, menumbuhkan rasa bangga serta sikap menghargai diri sendiri, pekerjaan dan orang lain. Manfaat Pelatihan Pemusatan Perhatian akan lebih optimal sejauh pelaksanaannya tetap memakai prinsip-prinsip pemusatan perhatian, yaitu: kesadaran (awareness), pengalaman saat ini atau fokus pada peristiwa sekarang, penerimaan, serta dilaksanakan secara rutin dalam kehidupan sehari-hari.

\section{Rekomendasi}

Berdasarkan hasil diskusi, peneliti menyampaikan beberapa rekomendasi untuk kalangan profesional maupun untuk peneliti selanjutnya.

Rekomendasi kepada kalangan profesional. Rekomendasinya adalah sebagai berikut:

1. Hasil penelitian yang menunjukkan bahwa Pelatihan Pemusatan Perhatian dapat meningkatkan empati perawat, diharapkan dapat menambah khasanah keilmuan psikologi serta dijadikan acuan dan program alternatif dalam upaya peningkatan manajemen mutu pelayanan keperawatan.

2. Pelatihan pemusatan perhatian dapat digunakan sebagai salah satu program untuk meningkatkan empati perawat dan dilaksanakan secara periodik dan berkesinambungan.

Rekomendasi kepada peneliti selanjutnya. Beberapa rekomendasi untuk peneliti selanjutnya adalah:

1. Perlunya dilakukan monitoring secara berkesinambungan di luar jam pelatihan untuk memastikan bahwa partisipan memahami materi dan mengaplikasikan latihan meditasi dalam kehidupan sehari-hari.

2. Pengaturan jadwal pelatihan juga harus lebih mempertimbangkan kesempatan dan keleluasaan partisipan untuk melakukan latihan di rumah.

3. Waktu pelaksanaan pelatihan perlu lebih menyesuaikan dengan jadwal kerja partisipan, sehingga faktor kelelahan setelah bekerja yang dapat mengganggu konsentrasi partisipan menjalani pelatihan dapat dihindari.

4. Evaluasi proses pelatihan sebaiknya menggunakan pertanyaan terbuka, sehingga tidak membatasi partisipan dalam memberikan jawaban. 
5. Lembar persetujuan partisipan (informed consent) harus menjelaskan lebih rinci mengenai efek samping atau resiko ketidaknyamanan yang dapat dihadapi oleh partisipan dan apa yang akan dilakukan oleh peneliti apabila hal itu terjadi. Selain itu, partisipan juga berhak untuk mendapatkan salinan lembar persetujuan (informed consent) sebagai pegangan selama proses penelitian berlangsung.

\section{Daftar Pustaka}

Allen, N.B., \& Knight, W. E.J. 2005. Mindfulness, Compassion for Self and Compassion for Others. Compassion, Conceptualisations, Research and use in Psychotherapy. Editor: Gilbert, P. London \& New York: Routledge Tailor \& Francis Group

Anna, S; Roonberg, S., \& Bodlund, O. 2006. Mindfulness-Based Cognitive Attitude Training for Primary Care Staff: a Pilot Study. Complementary Health Practice Review, 11, 144-152.

Beddoe, A.E., \& Murphy, S.O. 2004. Does Mindfulness Decrease Stress and Foster Empathy among Nursing Student. Journal of Nursing Education, 43, 305-312.

Block-lerner, J., Adair, C., Plumb, J. C., Rhatigan, D.L., \& Orsillo, S.M. 2007. The Case for Mindfulness-Based Approaches in The Cultivation of Empathy: Does Nonjudgemental, Present-Moment Awareness, Increase Capacity for PerspectiveTaking and Emphatic Concern. Joumal of Marital and Family Therapy, 33, 501-516.

Brehm, S. S., \& Kassim, S. M. 1993. Social Psychology. Boston: Houghton Mifflin Company.

Connelly, J.E. 2005. Narrative possibilities: using mindfulness in clinical practice. Perspective in Biology \& Medicine, 48, 84-94.

Davis, L.W., Strasburger, A.M., \& Brown, L.F. 2007. Mindfulness an Intervention for Anxiety in Schizophrenia. Journal of Psychosocial Nursing, 45, 23-29.

Eisenberg, N. 2004. Empathy and Sympathy. Dalam Lewis \& Havilands-Jones (Eds.). Handbook of Emotion. NewYork: The Guilford Press.

Germer, C. K. G. 2005. Mindfulness. What is it? What does it matter?. Dalam Germer, C. K. G., Siegel, R. D., \& Fulton, P. R. (Eds.) Mindfulness and Psychotherapy (h. ). NewYork: The Guilford Publications.

Grieshaber, C. 1994. Step by Step Group Development. Feldafing : German Foundation for International Development, Centre for Food and Agriculture Development.

Gunarsa, S.D., \& Gunarsa, Y.S. 1989. Psikologi Perawatan. Jakarta: PT BPK Gunung Mulia.

Halpern, J. 2007. Empathy and patient-physician conflict. Society of General Internal Medicine, 22, 696-700. 
Helen, S., \& Teasdale, J.D. 2004. Mindfulness-Bsed Cognitive Therapy for Depression: Replication and Exploration of Differential Relapse Prevention Effects. Journal of Consulting \& Clinical Psychology, 72, 31-40.

Hemmerdinger, J.M; Stodaart, S.D \& Lilford, R. J. 2007. A Systematic Review of Test of Empathy in Medicine. BMC Medical Education, 7, 24.

Hojat, M; Magione, S., Nasca, T.J., \& Gonnella, J.S. 2005. Empathy Scores in Medical School and Ratings of Empathic Behavior in Residency Training 3 Years Later. The Journal of Social Psychology, 145, 663-672.

Kinerja Klinis Perawat dan Bidan Ditingkatkan. Diunduh tanggal 19 Februari 2008, dari http://www.republika.co.id/arsip.asp? domains=www.republika.co.id\&q= perawat\&sa $=$ Cari\&sitesearch $=$.

Mathias, D., Filip, R., Mia, L., Sara, L. \& David, D. 2008. Mindfulness Skills and Interpersonal Behaviour. Personality \& Individual Differences, 44, 1235-1245.

Mercer, S.W., \& Reynold, W.J. 2002. Empathy and Quality of Care. British Journal of General Practice, 9-12.

Nurachmah, E. 2008. Asuhan Keperawatan Bermutu di Rumah Sakit. Diunduh tanggal 27 Februari 2008, dari www.pdpersi.co.id.

Planalp, S. 1999. Communicating Emotion. Social, Moral and Cultural. United Kingdom: Cambridge University Press.

Rohan, K. J. 2003. Mindfulness-Based Cognitive Therapy for Depression: Book essay and review. Psychiatry, 66, 272-280

Shapiro, S.L; Schwaartz, G.E. \& Bonner, G. 1998. Effect of Mindfulness-Based Stress Reduction on Medical and Premedical Student. Journal of Behavioral Medicine, 21, 581-599.

Singh, N. N., Lancioni, G. E., Joy, S. D. S., Winton, A. S. W., Sabbawi, M., Wahler, R. G., \& Singh, J. 2007. Adolesecents with Conduct Disorder Can Be Minful of Their Aggresive Behavior. Journal of Emotional and Behavioral Disorder, 15. 56-63

Staub, E. 1978. Positive Social Behavior and Morality. Social and Personal Influence. New York:Academic Press.

Strayer, J., \& Eisberg, N. 1990. Empathy and its Development. USA : Cambridge University Press.

Stepien, K.A., \& Baernstein, A. 2006. Educating for Empathy. Journal of General Intern Medical, 21, 524-530.

Yalom, I.D. 1985. The Theory and Practice of Gorup Psychotherapy Second Edition. New York: Basic Books, Inc. 
